\title{
POLICY ANALYSIS ON INSTITUTIONALIZATION OF HOUSING AND REGION SETTLEMENT
}

\author{
Mendra Wijaya ${ }^{1} \&$ T. Fahrul Gafar ${ }^{2}$ \\ Department of Government Studies \\ Islamic University of Riau (UIR), Pekanbaru \\ email:mendra.wmsi@gmail.com \\ ${ }^{2}$ Department of Government Studies \\ University of Abdurrab (Univrab), Pekanbaru \\ email: gaffar@univrab.ac.id
}

\begin{abstract}
The distribution of government task is divided into two kinds, the absolute task performed by the central government; and concurrent task (the task of choice and mandatory) that are a joint task between the central and local governments. Based on Law Number 23 the Year 2014 on Regional Government, the task of housing and settlement area is a mandatory task (basic service) of the (central and local) government tasks. However, there is a policy change that states that providing housing is not only a government (central and local) task, but also requires the involvement of other government agencies associated with this task, thus have to create a separate unit of work in handling it. Therefore, this paper aims to identify and analyze various policies and institutional coordination in the field of Housing and Settlement Area with the approach of Law of Governance, then provide solutions to efforts in increasing the institutional capacity so as not to overlap.
\end{abstract}

Keywords: policy analysis, institutionalization, housing, region settlement

\section{INTRODUCTION}

As it has been stated in the 1945 Constitution of the Republic of Indonesia, there are government tasks which become the authority of central government known as (1) Absolute tasks, and (2) Concurrent (together) tasks. The latter is divided into (1) Mandatory tasks, and (2) Optional tasks including central, provincial, and regency/ city government duties. Mandatory tasks are contained in two categories (1) Mandatory tasks dealing with basic services; and (2) Mandatory tasks having nothing to do with basic services. These related to Minimum Service Standard (Standar Pelayanan Minimum) are to guarantee people constitutional rights.

Implementation of the tasks is classified into three criteria, namely external matter, accountability and efficiency by considering harmonious relationship among government structures as a system of authorities between central, provincial, and regency/city government related each other (Sunarno, 2006, p.35). Tasks of local government include basic services, mandatory and optional tasks. Mandatory tasks are government business focused on basic services such as education, health, job, space, housing and settlement, security, law and order, people protection, and social 
sector. And there are mandatory tasks of government that have nothing to do with services like workers; woman empowerment and child protection; food; land; environment; demography and cencus; empowering village society; fertility control and family planning; communication and information; co-operative; small enterprise and so on. And optional tasks deal with potentiality and local uniqueness.

Based on the description, the housing aspect is one of the important issues to be discussed because house is basic requirement that must be fulfilled by the government which is called the obligatory service of basic service. This aspect of housing and residential areas is very complex, not just a matter of building but also other aspects such as land, material, environment and social, economic, and cultural fields to create harmonious relationships in society. The problems arise when there is a policy change stating that providing housing is not only government (central and local) task but also requires involvement of other government agencies associated with this task, thus have to create a separate working unit in handling it which also requires an improvement effort in institutional capacity to avoid mutual overlap.

\section{LITERATURE REVIEW}

Public policy is an interdependent model that is complex and has colective choices related to each other including unimportant decisions made by institutions or government offices. Jenkins defines state policy as a set of interrelated taken by a political actors or groups concerning the selection of goals and the means of achieving them within a specified situation where these decisions should, in principle, be within the power of these actors to achieve. Here it can be concluded that policy is inextricably linked to anything what the government says and does especially regarding programmes and its applications, laws, directives, and guidelines on how to achieve an agreement and common goals for people who involve in groups and organizations (Yudianti, 2007, p.192).

Government policies facilitate problem solving, and become implementation guidance and determined objectives. Policy refers to specific guidelines, methods, procedures, rules, forms, and administrative practices established to support and encourage works towards stated goals (Yudianti, 2007, p.192). The word of policy has English origin, and it is often used in affairs of the state or government, while the 
term of wisdom means an ability to make sensible decisions because of the experience and knowledge that somebody has. But there are scholars sometimes translating policy (kebijakan) as wisdom (kebijaksanaan) (Yudianti, 2007, p.192).

Generally, policy can be grouped into three stages (Abidin, 2004, p.31-33) :

1. Public policy is a policy becoming implementation guidelines including the whole areas and related institutions.

2. Policy implementations are policies outlining public policy. For central government, it is known as government regulations on implementations of acts.

3. Technical policy is policy operations under policy implementations.

Hence, public policy is closely related to public administration when public actor coordinates all activities linked to tasks in order to fulfill the basic requirements. For this reason, public administration is necessary to exist (Islamy, 1997, p.1). It has important roles in formulating government policies, and is a part of political processes. Public administration in attainng purposes usually make programmes and carry out activities manifested in the policy (Islamy, 1997. p.1).

It has generally known that Maslow develops a theory on how every motivation is interrelated. He names his theory as "necessary hierarchies". Every need has different levels. When a level has been fulfilled, people do not have motivation to get what they have. Furthermore they are going to try attaining the next needs. Maslow classifies levels of human needs as following: (1) psychological needs including fundamental needs such as food, home, sexs, oxygen, and other physical needs; (2) needs for security, for example safety and protection from sufferings; (3) social needs containing needs for love, affection, acceptance, and friendship; (4) needs for honour including internal factors namely dignity, freedom, and achievement; and external factors like status, acknowledgement, attention; (5) needs for self actualization including desire to be a better peson.

One of important measures in fulfilling needs for houses of citizens is housing development and settlement areas that principally has purposes to prepare locations for housing construction with its proper infrastructures and utilities. Parwata (2004) argues that settlement area is a living place for people that has been planned and shows clear aims. So it gives comfortable conditions to its inhabitants. Settlement is a process where someone reaches and lives in a region (Van der Zee 1986). The 
uses of a settlement is to not only provide for living space and protect offices but offer service, communication, education and recreation facilities as well.

In the national scale, needs for houses are relatively large in which they include new houses (backlog) around 4,3 million units; the growth of new houses every years is about 800 thousand units; and the need for raising quality of unproper houses to be resided by people is around 13 million units (statement of Minister of settlement and Region Infrastructure, 2002). These conditions cause environmental problems especially to the inner-city where there will be producing sick districts and neighbourhoods indicated by the rise of settlement and squatter areas, damage of historical sites, traffic congestion, the harm of water absorption areas, river sides, and beaches, disorder of public spaces, pedestrian areas, contents and the meaning of communities, discontinuities of city ecology and differences in city's morphology and typology.

Based on these issues, this article specifically aims to identify and to review the related policies, and how organizational coordination should be done in the implementation of the policy.

\section{METHOD}

This article is written in a normative legal approach, which uses normative case studies in the form of legal behavior products, such as reviewing laws. The subject of the study is a law that is conceptualized as a norm or rule that applies to society and becomes a reference for everyone's behavior. So that the normative legal approach focuses on positive legal inventories, legal principles or doctrines, legal discovery, and legal systematics by way of inventorying and identifying related policies according to the study problem and then reviewing and analyzing that problems.

\section{DISCUSSION}

\section{Policy Identification Regarding Central-Local Government Relations in Realizing Government Tasks on Housing and Region Settlement}

Because the authors have limited opportunities in this article to elaborate on various policies on housing and region settlement, here we identify these policies based on two main considerations arranged in the form of pointers to simplify the others to 
search for further information regarding these policies. The first is observations regarding the whole policies about relations between central and local government on the implementation of housing and settlement tasks. The second is reviews toward technical policies in carrying out these government tasks. The complete policies we could identify are below :

1. Law Number 17 Year of 2007 on National Long Term Development Plan Year 2005-2025

2. Law Number 2003 Year 2014 on Local Government

3. Law Number 25 Year 2004 on National Development Planning System

4. Government Regulations Number 65 Year 2005 on Arranging Guidance and Minimum Service Standard Implementation

5. Presidential Regulation Number 2 Year 2015 on National Middle Term Development Plan 2015-2019.

6. Technical policies on realizing housing tasks can be identified below :

7. Law Number 1 Year 2011 on Housing and Slum Areas

8. Law Number 20 Year 2011 on Flats

9. Law Number 26 Year 2007 on Spatial Planning

10. Government Regulation Number 88 Year 2014 on Development of Housing and Slum Areas

11. Public Housing State Minister Regulation Number 22 Year 2008 on Minimum Service Standard of Provincial-City Public House.

Coordinating Organizations on Implementing Government Tasks in Housing and Region Settlement based on:

a) Presidential Decree Number 121/P Year 2014

According to Presidential Decree Number 121/P Year 2014, there are 34 state ministries containing 13 changed ministries and 21 unchanged ministries. There are two new ministries - Coordinating Ministry of Maritime Affairs, Ministry of Agrarian and Spatial Planning/ National Land Agency; one ministry with new nomenclature viz. Coordinating Ministry of Human Development and Culture; and 10 ministries possessing new functions such as Coordinating Ministry on Economic Affairs, Coordinating Ministry of Political, Legal and Security Affairs, Ministry of Home Affairs, Ministry of Rural Affairs, Ministry of 
Countryside Development, Ministry of Public Works and Public Housing, Ministry of Tourism, Ministry of Environment and Forestry, Ministry of Education and Culture, Ministry of Research, Technology and Higher Education, Ministry of Manpower.

There are 21 unchanged ministries for instances Ministry of Finances, Ministry of Religious Affairs, Ministry of Defence, Ministry of Foreign Affairs, Ministry of Law and Human Rights, Ministry of Industry, Ministry of Health, Ministry of Transportation, Ministry of Trade, Ministry of Agriculture, Ministry of Social Affairs, Ministry of Commucation and Information, Ministry of Energy and Mineral Resources, Ministry of Maritime Affairs and Fisheries, Ministry of State's Owned Enterprises, Ministry of State Apparatus and Bureaucratic Reform, Ministry of Cooperation, and Ministry of Youth and Sports, Ministry of Woman Empowerment and Child Protection, Ministry of National Development Plan, and Ministry of State Secretariat. The duties of Ministry of Home Affairs are to realize tasks in domestic levels to assist President in exercising power. One of its functions is formulating, deciding and implementing policies in the fields of politics and government, regional autonomy, administration, rural government, government task and regional development, local finance, demography and cencus.

\section{b) Presidential Decree Number 11 Year 2015 on Ministry of Home Affairs}

This Ministry is founded on Presidential Decree Number 7 Year 2015 on Organizations of State Ministries, and Presidential Decree Number 11 Year 2015 on Ministry of Home Affairs. Organizations and Working Structures of the Ministry are decided through Regulation of Minister of Home Affairs Number 43 Year 2014 on Organization and Working Structure of Minisrty of Home Affairs officially legalized on April 10, 2015.

c) Minister Regulation Number 43 Year 2015 on Organization and Working Structure of Home Affairs Ministry

In the Article 4 of this regulation (Minister Regulation Number 43 Year 2015 on Organization and Working Structure of Home Affairs Ministry), organizational orders of the Ministry consists of : 
1. Secretariat General

2. Directorate General of Politics and General Administration

3. Directorate General of Territorial Administration Development

4. Directorate General of Regional Autonomy

5. Directorate General of Regional Development

6. Directorate General of Village Administration Development

7. Directorate General of Regional Finance Development

8. Directorate General of Populations and Civil Registry

9. Inspectorate General

10. Human Resource Development Agency

11. Research and Development Agency

12. Senior Advisor.

Regarding Directorate General of Regional Development, it is regulated in Chapter 6 of Minister Regulation Number 43 Year 2015 on Organization and Working Structure in Ministry of Home Affairs. This directorate has jobs to formulate and implement policies in both government tasks and directing regional development in accordance with regulations. This directorate consists of :

1. Secretariate of Directorate General

2. Directorate of Planning, Evaluation, and Regional Development Information

3. Directorate Synchronization of Regional Goverments Affairs I

4. Directorate Synchronization of Regional Goverments Affairs II

5. Directorate Synchronization of Regional Goverments Affairs III

6. Directorate Synchronization of Regional Goverments Affairs IV.

Directorate Synchronization of Regional Goverments Affairs II is regulated in Article 639 Minister Regulation Number 43 Year 2015 on Organization and Working Structure of Ministry of Home Affairs. This directorate has jobs in conducting some duties of General Directorate of Local Development in implementing government tasks and harmonizing regional development in the fields of public works, housing and slum areas, seas and fisheries, 
transportation, communication, information, statistics and encoding. The Directorate consists of :

1. Sub directorate of Public Work

2. Sub directorate of Transportation

3. Sub directorate of Maritime and Fisheries

4. Sub directorate of Housing and Region Settlement

5. Sub directorate of Administration

6. Sub directorate of Communication, Information, Statistics and Enconding.

In the article 646 of the Minister Regulation, Sub directorate of Housing and Region Settlement is of tasks to prepare and implement policies, conduct supervising jobs, coordinate and map government tasks, organize minimum service standards, arrange norms, standards, procedures, and criteria on realizing, controlling, reporting and evaluating government tasks, provide technical direction, syncronize local development in housing and region settlement. This sub-directorate has several functions such as:

1. Preparing policy formulation and facilitating realizations of government tasks related to local government, syncronizing regional development in housing and slum areas.

2. Preparing policy implementation and coordinating government tasks, and harmonizing regional development in housing and region settlement.

3. Setting up general guidelines and coordinating task implementation on local government in housing and region settlement.

4. Providing materials for coordination and mapping government tasks in housing and slum areas.

5. Serving coordination and facilitating minimum service standards of government tasks in housing and slum areas.

6. Preparing coordination and facilitating formations of norms, standards, procedures and criteria in implementing government tasks in housing and region settlement.

7. Preparing subtances for monitoring, evaluating, reporting realizations of local government tasks, and syncronizing local development in housing and region settlement; providing for giving technical directions and 
supervising its implementations in the level of local government, harmonizing its development.

\section{Policy Analysis on Housing and Region Settlement}

a) Policy Reviews on Implementation of Government Tasks in Housing and

\section{Region Settlement}

In accordance with previous explainations, it has been described that policies regulating implementations of government tasks as syncronizing foundations between central and local government in order to achieve national development goals. Therefore there are policies technically organizing task implementations in housing and slum areas. In decentralization perspectives, autonomous regions are not extensions of previous regions. But they are founded according to Government Acts where regional potentiality can be developed.

The birth of Law Number 23 Year 2014 on Local Government has consequences towards the distribution in implementing local government tasks. In the previous law, Law Number 32 Year 2004 on Local Government, government tasks were distributed according to tasks fallen under authority of central or local governments, and mandatory and optional tasks. But in the new Law, government tasks are divided into absolute tasks conducted by central government, competition tasks including both mandatory and optional tasks known as konkruen where these are shared with central, provincial, regency and city governments.

In mapping mandatory tasks that are not related to basic services and optional tasks, local government follows parameters decided by Ministries/Institutions. After fulfilling requirements, mandatory tasks having nothing to do with both tasks previously mentioned can be established as Local Apparatus Working Unit (Satuan Kerja Perangkat Daerah/SKPD) regulated in regional rules. The arrangements can be mapped here: 


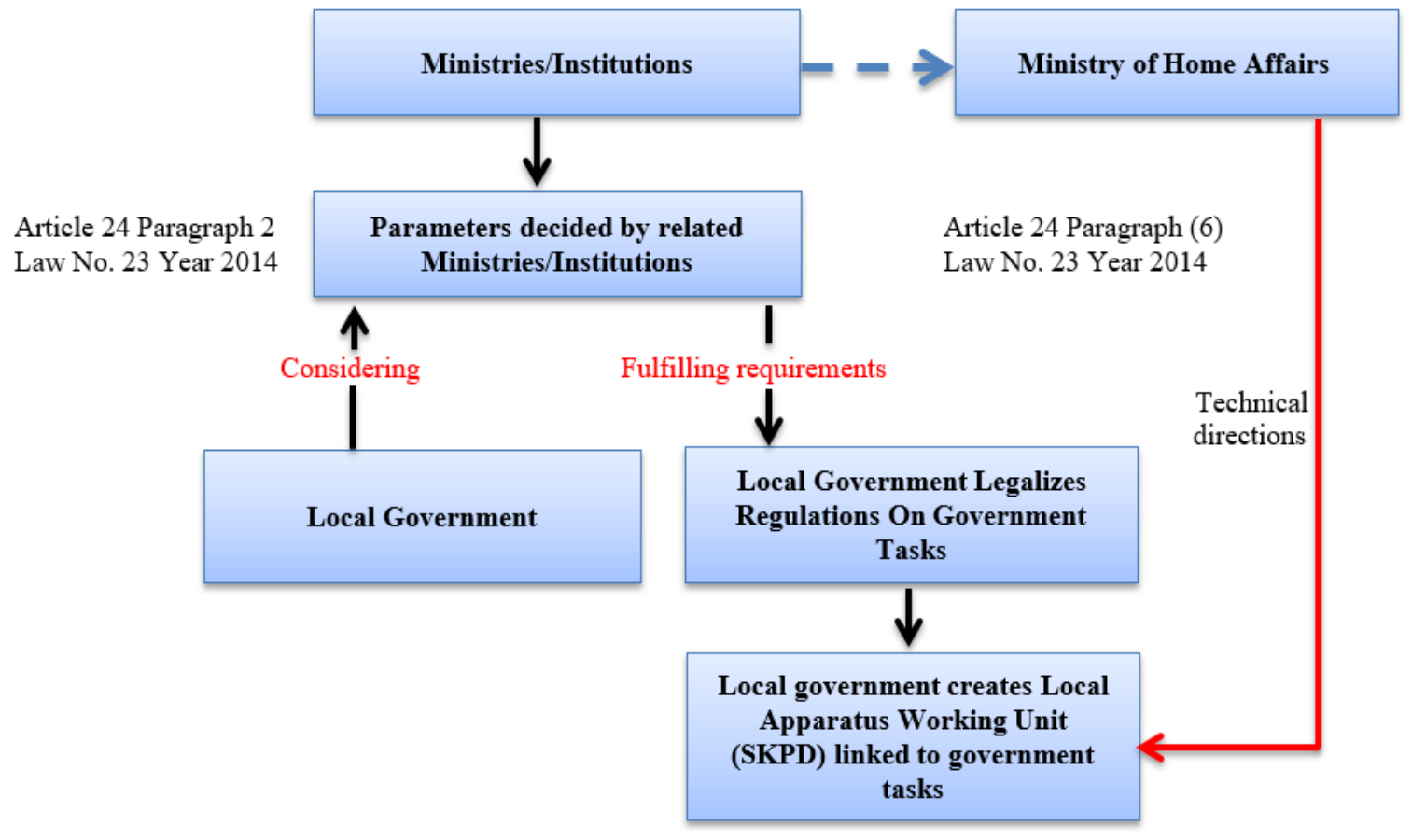

Fig. 1. Decided design on non-basic service mandatory tasks and optional tasks related to the creation of Local Apparatus Working Unit (Law No. 23/2014).

Implementation of mandatory tasks linked to basic services in accordance with Article 11 Paragraph (3) is the tasks where as the subtances are fundamental services. Local government runs several priorities in mandatory tasks related to services (Article 18 Paragraph 1). In the Article 17 Paragraph 1 , local government has autorities to decide policies for the purpose of his regional interests.

From the analysis above, it can be assumed that implementation of mandatory tasks related to services is a must. Local government is asked to give priorities because standards in running mandatory tasks linked to services differ from the tasks that are optional and unrelated to services. 


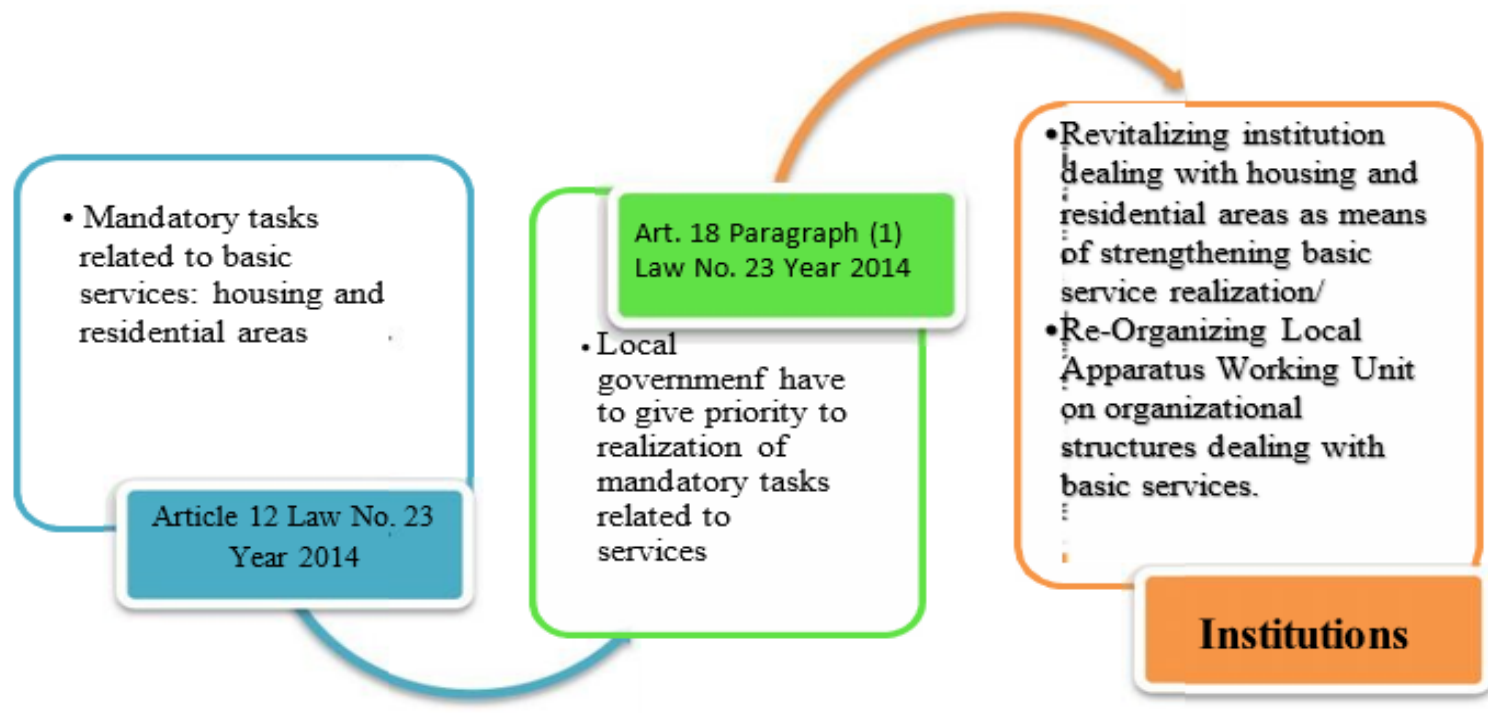

Fig. 2. Basic assumptions of mandatory task implementation on services.

Although there is no norm that specifically regulates institution reinforcement in conducting government tasks in basic service mandatory tasks like regulations on tasks that are unrelated to services and optional tasks, it does not mean that the running of mandatory tasks becomes government priorities, and these should include organizational improvement facilitated by Local Apparatus Working Unit led by units of Echelon II.

The problems of housing and region settlement have to do with development processes, and these generally reflect undeveloped effects. Housing development and residential areas will degrade environment qualities and to some extent create slum areas if the processes are not integrated, directed, planned, and do not entirely consider main infrastructures like water, sanitation, trash management, and drainage. Rapid population growth impacts many aspects for example living spaces, social and economic sectors where these things finally require proper infrastructures. The lack of infrastructures cause the rise of region settlement in the cities.

Due to the fact that housing and residential areas are basic service mandatory tasks of the government, organizational structures of these sectors in local governmend are expected to be main priority by considering resource, mindset, working time, financial ability of local government. It has been described that there are six mandatory tasks delegated from central to local government. And tasks on basic services has to be placed as top priority. 
Afterwards, local government has to give priority to six tasks on basic services mentioned in Paragraph 12 (Law Number 23/2014) that is : education; health; public work and spatial planning; housing and residential areas; security, public order, people protection; and social sector. These six basic services are considered as most important aspects completed with financial supports, human resources, infrstructures and management until these are abel to work very well in local government.

Development of housing and residential areas will directly contribute to people welfare. These are because development is able to support the growth of region and economy, social and cultural foundation, opportunities for employment, poverty erasing, and prosperity. Hence, the development process must be based on integrated and comprehensive policies, strategies and programmes, and activities until it can fulfill people rights in order that they have proper houses to live.

\section{b) Strengthening Implementation of Government Tasks in Housing and Region Settlement between Central and Local Government}

The content of Article 1 Paragraph 4 Law Number 17 the Year 2007 on National Long-Term Development Plan 2005-2025 mentions that Regional Middle Term Development Plan is a document for regional development for the period of five years containing explanations of visions, missions, and programmes of local government leaders using local and national development plans as guidance.

Regional Medium-Term Development Plan emphasizes the importance to articulate visions, missions, and agendas of elected chiefs in the forms of goal, target, strategy and policy development accommodating people aspirations and agreements on indicators to assess whether local development in the next five years succeeds or not.

It is a planning document about management and strategy for five years arranged in accordance with what local people needs. It is adaptive and flexible. It is able to accommodate current development and utilize existing opportunities. It also describes services done by the government indicating the success of its institutions. Therefore service systems have to be appropriate for 
people needs and raise communication between government and people in conducting development.

Tabel 1. Regional Medium Term Development Plan In Indonesian Provinces

\begin{tabular}{|c|c|c|}
\hline $\mathrm{N}_{0}$ & Provinces & Regulations/Year \\
\hline 1 & Aceh & Regional RegulationNo. 6 Year 2012(2012-2017) \\
\hline 2 & North Sumatera & Regional RegulationNo.5 Year 2014(2013-2018) \\
\hline 3 & West Sumatera & Regional RegulationNo.4 Year 2014(2010-2015) \\
\hline 4 & Riau & Regional RegulationNo. 74 Year (20142019) \\
\hline 5 & Riau Archipelago & Regional RegulationNo. 03 Yex $2011(2010-2015)$ \\
\hline 6 & Jambi & Regional RegulationNo. 1 Year 2011 (2010-2015) \\
\hline 7 & South Sumatera & Regional RegulationNo. Year (2013-2018) \\
\hline 8 & BanglaBelitung Archipelago & Regional RegulationNo. 6 Year 2012 (2012-2017) \\
\hline 9 & Bengkulu & Regional RegulationNo Year (2011-2015) \\
\hline 10 & Lampung & \\
\hline 11 & Municipality of Jakarta & Regional RegulationNo 2 Yerr 2013(2013-2017) \\
\hline 12 & West Java & Regional Regulation No. Year 2013 (2013-2018) \\
\hline 13 & Banten & Regianal Regulation No 4 Year 2012 (2012-2017) \\
\hline 14 & Central Java & Regional Regulation No 5 Year 2014(2013-2018) \\
\hline 15 & Special Territory of Yogyakarta & Regicnal Regulation No. Year 2012 (2012-2017) \\
\hline 16 & East Java & Regicnal Regulation No. Year 2014 (2014-2019) \\
\hline 17 & Bali & Regional Regulation No. Year (2013-2018) \\
\hline 18 & Nusa Tenggara Barat & \\
\hline 19 & Nusa Tenggara Timur & Regional RegulationNo 01 Year 2014(2013-2018) \\
\hline 20 & West Kalimantan & Regicnal Regulation No. Year (2013-2018) \\
\hline 21 & Central Kalimantan & Regional Regulation No. 01 Yerr $2011(2010-2015)$ \\
\hline 22 & South Kalimantan & Regional Regulation No. Year 2014 (2011-2015) \\
\hline 23 & East Kalimantan & Regional Regulation No 7 Year 2014 (2013-2017) \\
\hline 24 & North Kalimantan & \\
\hline 25 & North Sulawesi & Regional Regulation No.4 Yerr 2011(2010-2015) \\
\hline 26 & Gorontalo & Regional Regulation No. 15 Year 2013 (2012-2017) \\
\hline 27 & Central Sulawesi & Regional Regultion Nomor Year (2011-2016) \\
\hline 28 & South Sulawesi & Regional Regulation No. 10 Year 2013 (2013-2018) \\
\hline 29 & West Sulawesi & Regional Regulation No 01 Yer 2013 (2012-2016) \\
\hline 30 & Southeast Sulawesi & Regional Regulation No 10 Year 2013 (2013-2018) \\
\hline 31 & Maluku & \\
\hline 32 & Maluku Utara & Regional Regulation No. Year (2014-2019) \\
\hline 33 & Papua & Regional Regulation No. 14 Year 2013 (2013-2018) \\
\hline 34 & West Papua & Regional Regulation No. Year (2012-2016) \\
\hline
\end{tabular}

Source: General Directorate Regional Development, Ministry of Home Affairs

From the table above, there are local governments that would implement Regional Medium Term Development Plan 2015-2020 where as this was 
related to election of local leaders 2015 in 263 provinces, cities and regencies. In Law Number 25 Year 2004 on National Development Planning System and Law Number 23 Year 2014 on Local Government, elected leaders have the duties of arranging Regiomal Middle Term Development Plan as a guideline in conducting development in the next five years. Strategic plans made by local leaders should be interpreted by Local Apparatus Working Unit as task force implementing Regional Medium Term Development Plan.

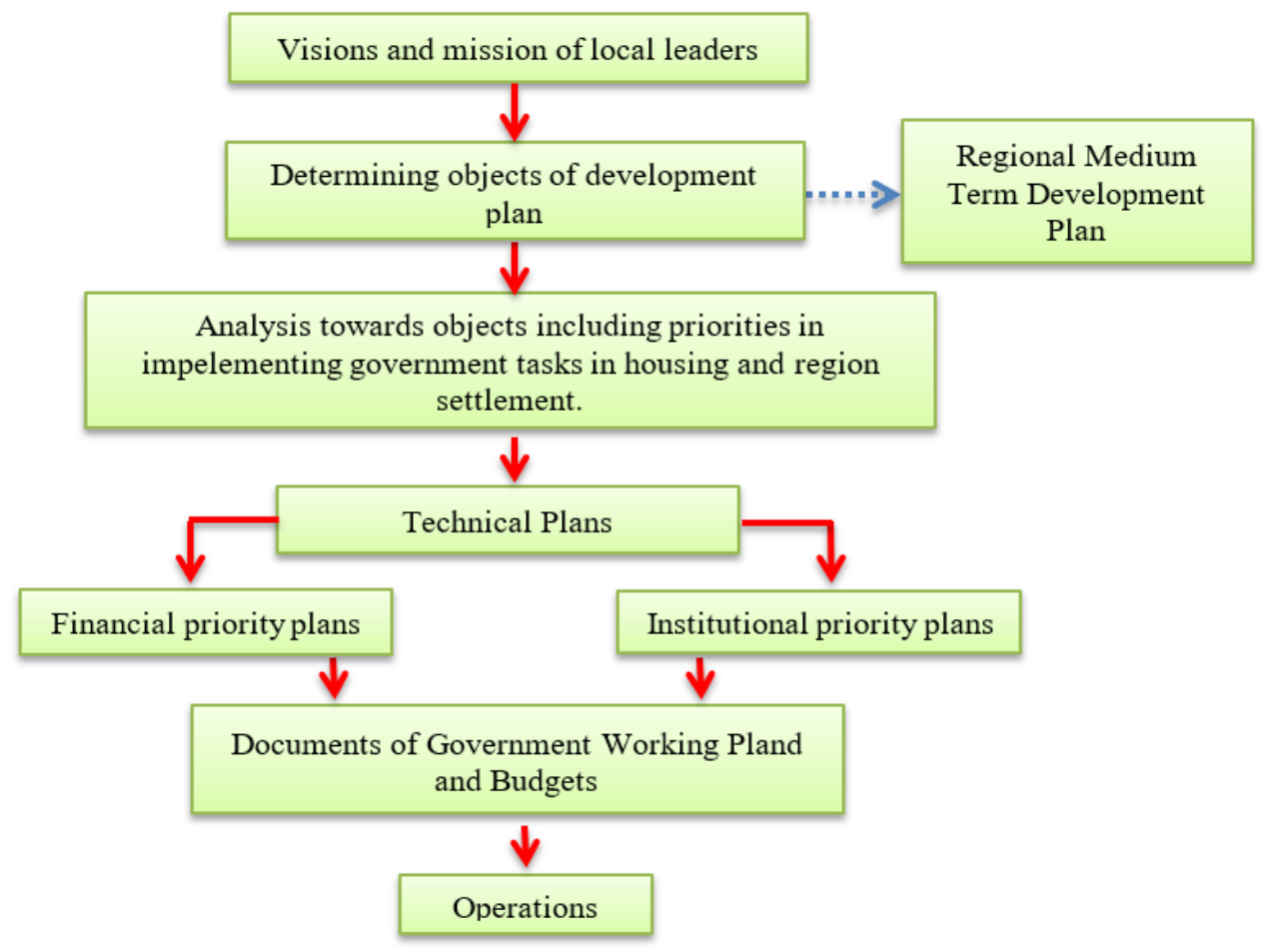

Fig. 3. Priority planning processes in housing and residential areas in formulating Regional Medium Term Development Plan

In formulating Regional Medium Term Development Plan 2015-2020, every local government is asked to give priority to housing and slum areas in accordance with Law Number 23 Year 2014 on Local Government stating that they are the subtances in serving slum areas as legitimacy that they are mandatory tasks on basic services regarded as main priority in local development. Therefore, implementation of these fields is under responsibility of eight related ministries including Ministry of National Development Planning Agency, Ministry of Home Affairs, Ministry of Public Work and Public Housing, Ministry of Health and Ministry of Environment nad Forestry where as Ministry of Home Affairs has control in coordinating to local government. 
In the 1945 Constitution of Indonesian Republic especially in the Article $28 \mathrm{H}$ Paragraph 1, it states clearly that every man has rights to live in proper places, have houses, and get healthy services. It places that having houses is man's rights and as a way of increasing his living condition. A house is a place for a family to not only reside but also educate family members. So housing development supported by proper spaces and good infrastructures is means of raising quality of Indonesia human resources in the future.

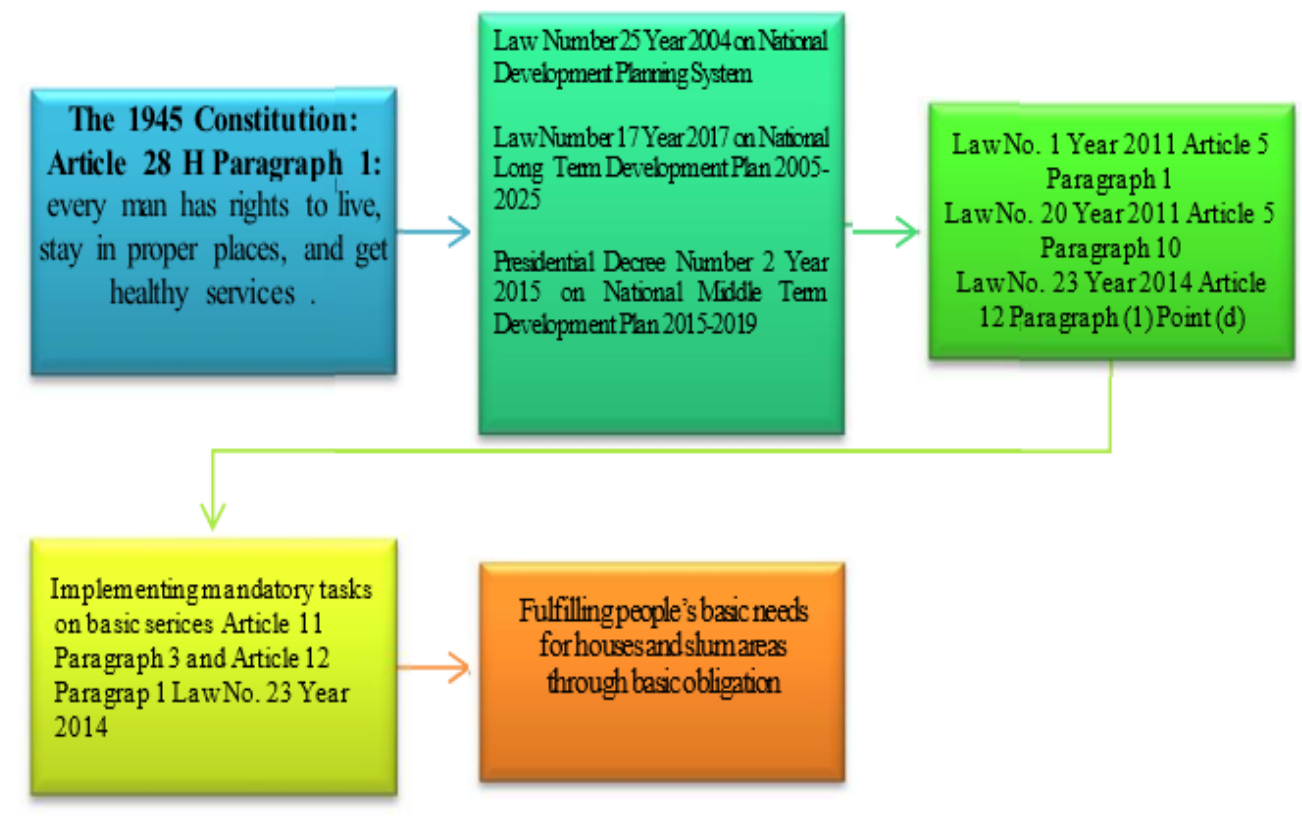

Fig. 4. Needs for houses are citizen rights guaranteed by constitutions

But these rights are not fulfilled. One of the causes is that there is a big gap in fulfilling needs for houses (backlog). This happens due to the tact that the lack of financial support had by people especially from lower classes.

According to data from Badan Pusat Statistik (Central Bureau of Statistics) in 2010, there are 13,5 million families in Indonesia that have no home (backlog) and unappropriate home around 7,6 million. Data from UNDP call that there are slums in Indonesia aound 59 thousand hectares. To solve these problems, the government is able to build houses around 200 thousand per year where 60 percent is in the cities. Moreover raising house quality is just 300 thousand per year, and slum areas can be handled about 275 hectares per year. So the government tries to formulate policies and its 
operations stimulating local government to parcitipate. In facts, local government has no authorized institutions to deal with these problems.

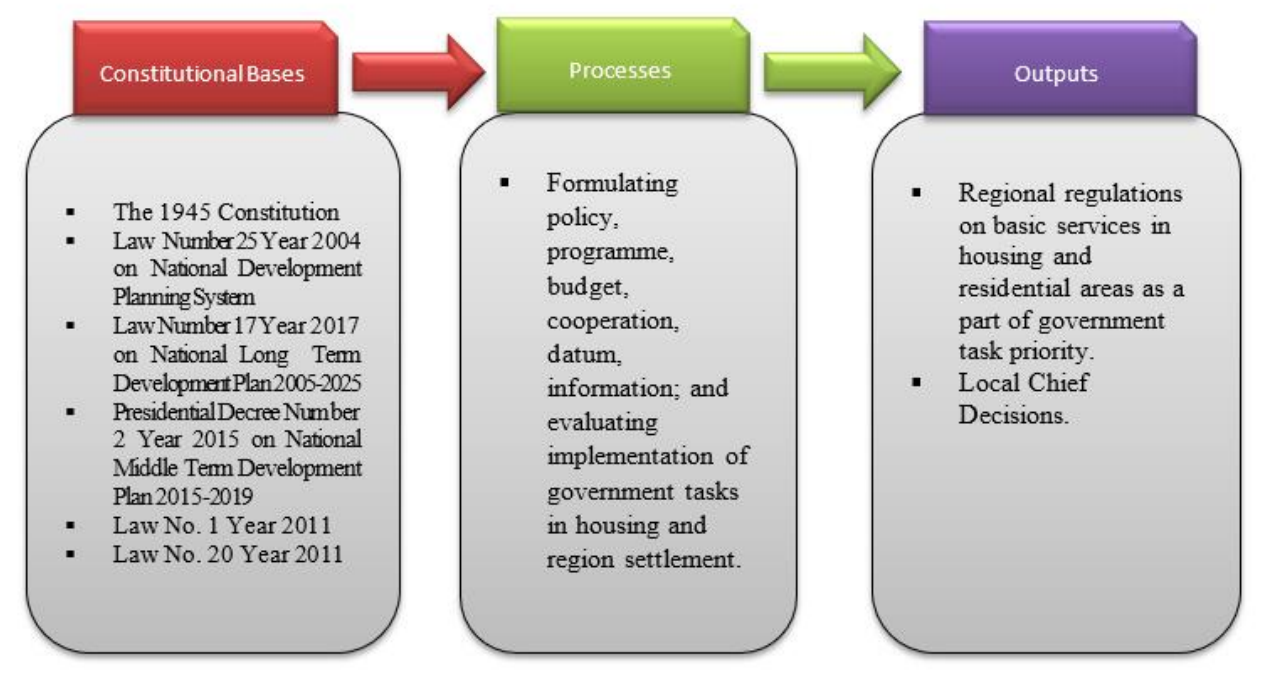

Fig. 5. Processes of policy establishments on government task implementation in housing and residential areas.

Revitalizing and repositioning institutions coordinating implementation of government tasks in housing and region settlement can be one by strengthening coordination and syncronization between central and local governments as means of institutional establishment dealing with housing and region settlement.

\section{CONCLUSION}

In order to apply decentralization, deconcentration, and provison of assistance, local government runs concurrent affairs differing from central government conducting absolute affairs. Concurrent affairs are divied into central and local governments. The distribution of the tasks is based on accountability, efficiency, external matter principles. And local autonomy is founded on these national strategic interests.

The existence of priority scales in implementing mandatory tasks aims at spreading autonomy, and these do not always mean institutionalization. But its functions are still local government domains, and these should not be institionalized because these will cause overhead costs. Strategies have important roles to institutionalize where as these are of small structures but many functions known as right sizing. These things are to maximize government performances according to its 
own authorities and to increase accountabilty and efficiency in measuring success. Moreover this distribution of tasks is to simplify bureaucratic channels at central and local government in serving people.

To increase implementation tasks in housing and region settlement mandated by laws, it is important to syncronize coordination between central and local government. Tasks in housing and slum areas are government interests that are integrated from central to local government where as syncronization on these tasks has to be supported by all stakeholders including private sectors. Actually, Law Number 23 Year 2014 on Local Government states that providing for basic services like housing and settlement is one of local government obligations. Nonetheless, central government must cooperate with local government by facilitating its subordinates in order to work well.

\section{REFERENCES}

Abidin, Said Zainal. (2004). Kebijakan Publik. Jakarta: Penerbit Pancur Siwah. [Abidin, Said Zainal. (2004). Public Policy. Jakarta: Penerbit Pancur Siwah.

Government Regulation Number 65 Year 2005 on Arrangement Guideline and Minimum Service Standard Application.

Government Regulation Number 88 Year 2014 on Housing Realizing Establishment and Slum Areas.

Huda, Ni'matul. (2009). Hukum Pemerintahan Daerah. Bandung: Nusamedia. [Huda, Ni'matul. (2009). Law of Local Government. Bandung: Nusamedia]

Islamy, Irfan M. (1997). Prinsip-Prinsip Perumusan Kebijakan Negara. Jakarta: Bumi Aksara. [Islamy, Irfan M. (1997). Formulating Principles of State Policy. Jakarta: Bumi Aksara].

Law Number 25 Year 2004 on National Development Planning System.

Law Number 17 Year 2007 on National Long Term Development Plan 2005-2025.

Law Number 26 Year 2007 on Spatial Planning.

Law Number 1 Year 2011 on Housing and Slum Areas

Law Number 20 Year 2011 on Flats

Law Number 23 Year 2014 on Local Government.

Maslow, Abraham H. (1984). Motivasi dan Kepribadian: Teori Motivasi dengan Ancangan Hirarki Kebutuhan Manusia. Terjemahan oleh Nurul Iman. Jakarta: 
PT. Pustaka Binaman Pressindo. [Maslow, Abraham H. (1984). Motivation and Personality: Theory of Motivation with Man's Hierarchical Need Approaches. Indonesian translation by Nurul Iman. Jakarta : PT. Pustaka Binaman Pressindo].

Parwata, I Wayan. (2004). Dinamika Permukiman Perdesaan Pada Masyarakat Bali. Denpasar: Direktorat Jenderal Pendidikan Tinggi. [Parwata, I Wayan. (2004). The Dynamics of Rural Settlements In Bali Society. Denpasar: Directorate General of Higher Edication].

Presidential Decree Number 2 Year 2015 on National Middle Term Development Plan 2015-2019.

Presidential Decree Number 11 Year 2015 on Ministry of Home Affairs.

Public Housing State Minister Regulation Number 22 Year 2008 on Minimum Service Standard of Provincial-City Public House

Regulation of Minister of Home Affairs Number 43 Year 2015 on Organization and Working Structures.

Sunarno, Siswanto. (2006). Hukum Pemerintahan Daerah di Indonesia. Jakarta: Sinar Grafika. [Sunarno, Siswanto. (2006). Local Government Laws in Indonesia. Jakarta: Sinar Grafika].

Yudianti, Thoyibbah Kundewi. (2007). Implementasi Kebijakan Rekayasa Ulang Organisasi Kantor Informasi dan Komunikasi di Sukabumi. Jurnal Mahkamah, Volume 19 Nomor 2, Oktober 2007. Fakultas Hukum, Universitas Islam Riau. Pekanbaru. [Yudianti, Thoyibbah Kundewi. (2007). Policy Implementation on Organizational Re-enginering of Information and Communication Offices in Sukabumi. Journal of Mahkamah, Volume 19 Number 2, October 2007. Faculty of Law, Islamic University of Riau, Pekanbaru]. 